\title{
Behavioral Differentiation and Ovarian Development of Unmated Gynes, Queens, and Workers of Ectatomma vizottoi Almeida 1987 (Formicidae, Ectatomminae)
}

\author{
Alexsandro Santana Vieira, ${ }^{1}$ Wedson Desidério Fernandes, ${ }^{2}$ \\ and William Fernando Antonialli-Junior ${ }^{3}$
${ }^{1}$ Programa de Pós-graduação em Entomologia e Conservação da Natureza, Universidade Federal da Grande Dourados. 241, 79804-970 Dourados, MS, Brazil
${ }^{2}$ Faculdade de Ciências Biológicas e Ambientais, Universidade Federal da Grande Dourados. 241, 79804-970 Dourados, MS, Brazil
${ }^{3}$ Laboratório de Ecologia do Centro de Análise Integrado e Monitoramento Ambiental, Universidade Estadual de Mato Grosso do Sul, 351 79804-907 Dourados, MS, Brazil

Correspondence should be addressed to Alexsandro Santana Vieira, alexsvieira@yahoo.com.br

Received 30 June 2011; Revised 14 July 2011; Accepted 22 July 2011

Academic Editor: Jacques H. C. Delabie

Copyright (c) 2012 Alexsandro Santana Vieira et al. This is an open access article distributed under the Creative Commons Attribution License, which permits unrestricted use, distribution, and reproduction in any medium, provided the original work is properly cited.

\begin{abstract}
Behavioral differentiation and ovarian development of unmated gynes, queens, and workers of Ectatomma vizottoi were investigated in laboratory conditions. Forty-one behavioral acts were identified and quantified for workers, 19 for queens and 24 for unmated gynes, for an overall species repertoire of 42 different behavioral acts. Ovipositing reproductive eggs was an exclusive task of the queen, whereas workers showed 15 caste-specific behaviors. The most important (frequent) behaviors for the queens were brood care, immobility, and reproduction, and for workers were immobility, grooming/interaction, brood care, and foraging. Unmated gynes (not winged) primarily showed immobility, brood care, grooming/interaction, and foraging. Analysis of ovarian development showed that unmated gynes had little-developed ovarioles, in contrast to queens. Queens and unmated gynes showed a clear behavioral differentiation, in which queens played the role of reproducers and unmated gynes performed activities belonging to the worker repertoire. Despite the presence of several breeding queens in the colony, functional monogyny was the rule.
\end{abstract}

\section{Introduction}

The basic characteristic responsible for the reproductive success of the social insects is the division of labor among the individuals of the colony $[1,2]$. This is an important topic for understanding the evolution of social behavior $[3,4]$. The behavior of different individuals in a colony of ants is controlled by a sophisticated system of transfer of information, which allows the entire colony to work as a single superorganism [1].

As discussed by Bolton [5] the group of poneromorph ants is very diverse, and the individuals show a mixture of basal and derived morphological and social characters. For example, morphologically and behaviorally, Amblyopone Erichson shows basal characteristics, while other genus of the
Amblyoponinae subfamily show derived characteristics, for example Prionopelta amabilis Borgmeier [6-8]. There is wide variation of behavior among the species of the poneromorph group, ranging from generalist predators that make use of a well-developed sting to dominate their prey, such as the Ponerinae Pachycondyla harpax Fabricius and Ectatomminae Ectatomma ruidum Roger, to others that are more limited in their feeding habits, such as Proceratium Roger, Proceratinae subfamily, which feeds on arthropod eggs, or Leptogenys Roger, Ponerinae subfamily, which feeds on isopods. Others, such as Ectatomma tuberculatum Olivier, add to their diet sweet substances secreted by hemipterans, secretions from the extrafloral nectary, or fallen fruit pulps $[9,10]$. The foraging pattern in this group is termed "social facilitation" [1] and is typical of species of small ant colonies such 
as E. ruidum, where the workers forage individually (each forager in its own hunting area) $[9,10]$.

There are two reproductive systems in ants, monogyny and polygyny. Hölldobler and Wilson [6] defined monogyny as the situation in which several queens are present in the colony, but only one is inseminated and able to produce fertile eggs. Polygyny refers to the occurrence of several queens in the same colony, all able to produce fertile eggs. This characteristic is present in many species of ants, and the number of queens can vary among and within the species [4]. As discussed by Brandão [11] there is a clear division of labor between queen and workers in monogynic colonies, in which the workers are responsible for most of the tasks; some examples are Ectatomma permagnum Forel [12] and Ectatomma planidens Borgmeier [13] (erroneously identified as Ectatomma edentatum Roger [14]). The subfamily Ectatomminae also includes several polygynous species, such as E. ruidum [15], Gnamptogenys striatula Mayr [16], and E. tuberculatum [17]. Also, social organization has been studied in some species of Ectatomma Smith, including E. tuberculatum [18], E. permagnum [12], Ectatomma brunneum (=quadridens) Smith [19], E. ruidum [20, 21], E. planidens [13], and Ectatomma opaciventre (Roger) [22, 23].

The nest of Ectatomma vizottoi has ellipsoid entrance and exit openings that lead to a wide tunnel, similar to a hall, which is connected to other chambers deeper in the nest. The nests are up to $360 \mathrm{~cm}$ deep and contain three to ten chambers. This species builds more elaborate nests than other species of Ectatomminae, and its colonies can have up to 10 queens [24]. This study investigated whether colonies of this species can also show behavioral and ovarian development that differentiates it from other members of the genus Ectatomma.

\section{Methods}

Three colonies of E. vizottoi were collected according to the methodology described by Antonialli-Junior and Giannotti [26], on the campus of UEMS-Universidade Estadual de Mato Grosso do Sul $\left(22^{\circ} 12^{\prime} \mathrm{S} 54^{\circ} 48^{\prime} \mathrm{W}\right)$, in August 2006. Behavioral observations were conducted, and the ovarian development of unmated gynes, queens, and workers was also evaluated. The behavioral observations continued from December 2006 until July 2007. The population composition of the colonies is described in Table 1.

2.1. Division of Labor. Ethograms of different species of ants have contributed to the quantification and qualification of the ways in which the tasks are divided among individuals $[27,28]$. Drogoul et al. [29] introduced the concept of the Structural Ethomodel (EMF), defining a method to model complex organizations such as social insect societies.

The reproductive and sterile castes were marked individually on the thorax with model-airplane paint, similarly to the method used by Nakata [30]. The colonies were kept in laboratory conditions at a temperature of $26^{\circ} \pm 2^{\circ} \mathrm{C}$, relative humidity $55-81 \%$, and a natural light cycle, in artificial nests $(28 \times 18 \mathrm{~cm})$, made of molded plaster with three
TABLE 1: Number of adult and immature individuals from three colonies of Ectatomma vizottoi collected on the campus of Mato Grosso do Sul State University, in August 2006.

\begin{tabular}{cccccc}
\hline Colonies & Queen & $\begin{array}{c}\text { Unmated } \\
\text { gyne }\end{array}$ & Workers & Males & $\begin{array}{c}\text { Immature } \\
\text { (larvae and } \\
\text { pupae) }\end{array}$ \\
\hline colony 1 & 1 & 1 & 92 & - & 7 \\
colony 2 & 1 & 2 & 82 & - & 55 \\
colony 3 & 1 & 4 & 123 & 11 & 222 \\
\hline
\end{tabular}

chambers and tunnels connecting them in the horizontal plane [13]. Each nest was maintained in a glass box $(68 \times$ $38 \times 30 \mathrm{~cm}$ ), which functioned as a foraging arena, and the ants were offered larvae of Tenebrio molitor L. (Coleoptera: Tenebrionidae) and a 1:1 honey-water solution as food, in addition to water.

We carried out 20 hours of qualitative observation, with the help of a hand lens, in sessions of 60 minutes each. We used the method of all occurrences ("ad libitum" sensu [31]) to define the main categories and behavioral acts of all unmated gynes, queens, and workers in the three colonies.

After this step, we carried out 121 hours of quantitative observation, in 60-minute sessions with intervals of 2 minutes after every 5 minutes, using the scanning sample method [31], totaling 43,270 reports. After the quantification of the behavioral acts, the sample coverage value was calculated, estimated according to Fagen and Goldman [32], calculated by the expression: $\theta=1-\left(N_{1} / i\right)$, with " $N_{1}$ " the number of behavioral acts observed only once and " $i$ " the total number of behavioral acts. The closer $\theta$ is to 1.0 , the better is the sample coverage. The study can be considered complete when $\theta$ ranges between 0.90 and 0.99 . The behavioral repertoires of queens, workers, and unmated gynes were compared through Morisita-Horn cluster analysis (multivariate analysis), which is most appropriate for percentage data [33]. The daily 24-hour cycle was divided into three periods (06:00-12:00 h, 12:00-18:00 h, and 18:00-06:00 h) to determine the peak foraging period.

All behavioral acts shown by E. vizottoi also occur similarly in other species. These acts have been described in detail for other species, for example E. planidens [13] and are therefore not described here.

2.2. Ovarian Development. For the comparative analysis of the ovarian development, 12 workers and 10 queens from the 3 colonies were anesthetized by thermal shock ( 3 to $5 \mathrm{~min}$. at $4^{\circ} \mathrm{C}$ ) and dissected in a Petri dish in a saline solution for insects, with the aid of a stereomicroscope. The ovaries were removed, and morphological data were obtained, as well as the number of ovarioles in each case, and then schematized.

\section{Results}

3.1. Ethogram. The sample cover value of the behavioral repertoire was $\theta=0.98$, showing 42 behavioral acts of which 41 were performed by workers, 19 by queens, and 24 by unmated gynes. The "ovipositing reproductive eggs" 


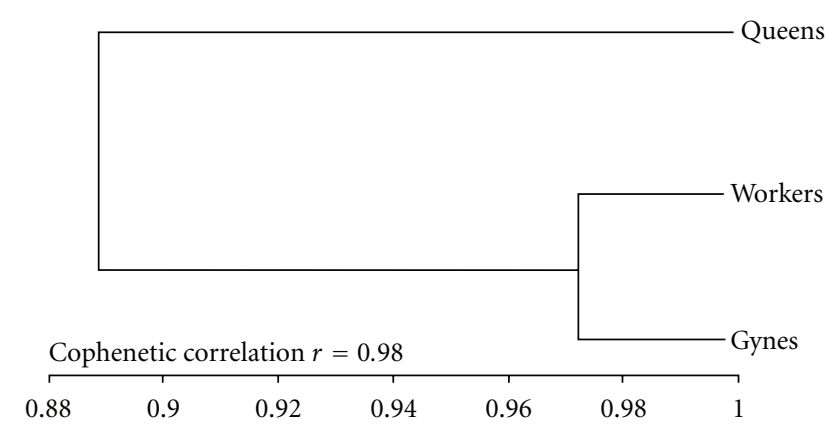

FIGURE 1: Dendrogram of similarity (Morisita-Horn) of the behavioral repertoires among the queens, workers, and unmated gynes of Ectatomma vizottoi.

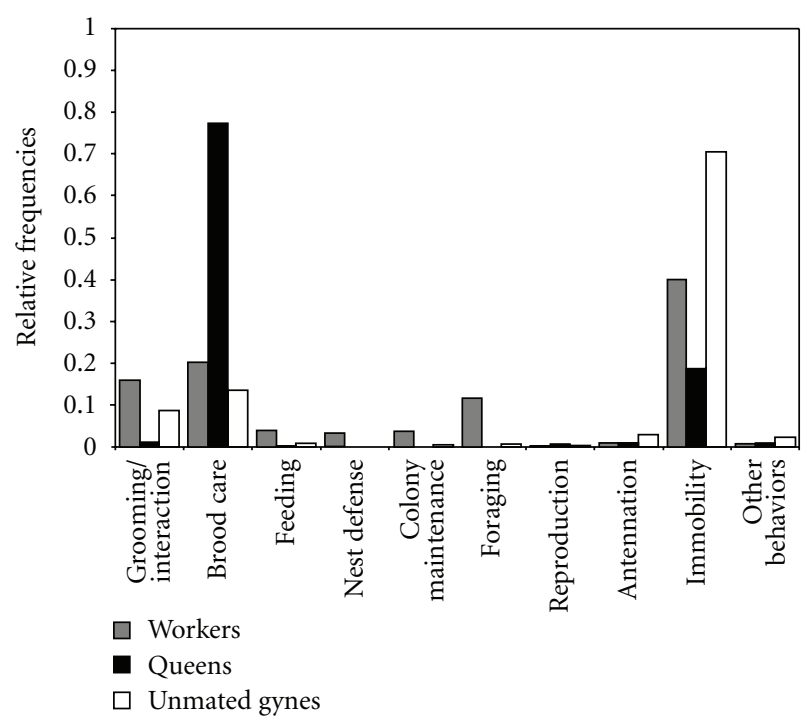

FIGURe 2: Relative frequency with which workers, queens, and gynes performed ten behavioral categories, in colonies of Ectatomma vizottoi under laboratory conditions.

was exclusive to only one queen in each colony, while the workers showed 15 exclusive behaviors (Table 2). Cluster analysis revealed that the unmated gynes showed a behavioral repertoire similar to the workers (Figure 1).

The behavioral tasks were grouped to 10 distinct categories. The queens were more effectively involved with the categories "brood care", "immobility", and "reproduction" (Table 2, Figures 1 and 2). Unmated gynes performed mainly tasks in the categories "immobility", "brood care", "grooming/interaction", and "foraging" (Table 2, Figures 1 and 2), while the repertoire of the workers was distributed in all the categories, mainly "immobility", "grooming/interaction", "brood care", and "foraging" (Table 2, Figures 1 and 2).

(A) Grooming/Interaction. In this behavioral category, eight behaviors were observed, of which the most significant were: "self-grooming of the 1st, 2nd, and 3rd pairs of legs", "selfgrooming of the gaster extremity", and "allogrooming in workers", most frequently performed by the workers; while the task "touch workers with antennas" was performed more frequently by unmated gynes (Table 2, Figure 2).

(B) Brood Care. Fourteen behavioral acts were observed in this category, which includes the tasks that are mostly performed by the queens, in comparison to unmated gynes and workers (Figure 2, Table 2), for example, "standing on or beside the pile of eggs", "standing on or beside the pile of larvae", and "standing on or beside the pile of pupae". On the other hand, the tasks "inspecting larvae", "licking larvae", and "inspecting pupae" were performed more frequently by the workers (Table 2).

(C) Feeding. Seven behavioral acts were included in this category, most of them were performed more frequently by workers and unmated gynes (Figure 2, Table 2). The tasks of "feeding larva with solid food" (pieces of prey), "feeding on solid food", and "worker-larva transfer of food" were notable. "Ovipositing trophic eggs" was performed only by workers and unmated gynes, and these eggs were whitish.

(D) Nest Defense. This category includes only the task of "guarding the entrance of the nest", which was performed by workers and unmated gynes (Figure 1, Table 2).

(E) Colony Maintenance. Four behavioral acts are included in this category, and they were performed only by workers and unmated gynes (Table 2, Figure 1). The queen performed only the task "inspecting the nest" (Table 2).

(F) Foraging. "Foraging" (Table 2, Figure 2) was defined as any activity outside the nest, including the search for any resource or transportation of detritus from the nest to the foraging arena. No forms of recruitment were observed for workers and unmated gynes in this activity. The peak of the "foraging" activity was during the morning, between 06:00 and 12:00. During the other periods the activity was continuous, decreasing gradually.

(G) Reproduction. Only the queens performed the task "ovipositing reproductive eggs" (Table 2, Figure 2).

(H) Antennation. This category involved the acts of antennating and being antennated by workers and queen and unmated gynes from the colony (Table 2, Figure 2).

(I) Immobility. Remaining immobile without performing any other task was the most frequent act among the unmated gynes, followed by workers and queens (Figure 2, Table 2).

(J) Other Behaviors. In this category the acts of "moving inside the nest", carrying workers and queens were observed, and the last three acts were performed only by the workers (Figure 2, Table 2).

3.2. Ovarian Development. The workers possess 1 or 2 ovarioles per ovary (Figure 3, IA-C). Three degrees of 
TABLE 2: Relative frequency of behavioral acts from the behavioral repertoire of workers, queens, and unmated gynes of Ectatomma vizottoi.

\begin{tabular}{|c|c|c|c|c|}
\hline Catę & gories and behavioral acts & Workers & Queens & Unmated gynes \\
\hline \multicolumn{5}{|c|}{ (A) Grooming/Interation } \\
\hline (1) & Self-grooming; 1st pair of legs & 0.05014 & 0.00672 & 0.04898 \\
\hline & Self-grooming; 2nd pair of legs & 0.01732 & 0.00134 & 0.01503 \\
\hline & Self-grooming; 3rd pair of legs & 0.01727 & 0.00134 & 0.01503 \\
\hline & Self-c grooming; extremity of the gaster & 0.00818 & 0.00134 & 0.00436 \\
\hline & Self-grooming of mandibles & 0.00010 & - & - \\
\hline & Allogrooming in workers & 0.04616 & - & 0.00436 \\
\hline & Allogrooming in queens & 0.01685 & - & - \\
\hline (8) & Allogrooming in males & 0.00297 & - & - \\
\hline \multicolumn{5}{|c|}{ (B) Brood Care } \\
\hline (9) & Standing on or beside the pile of eggs & 0.01957 & 0.31720 & 0.00048 \\
\hline (10) & Inspecting eggs & 0.00497 & 0.01613 & - \\
\hline$(11)$ & Carrying eggs & 0.00049 & 0.00403 & - \\
\hline$(12)$ & Licking eggs & 0.00163 & 0.00269 & 0.00048 \\
\hline$(13)$ & Standing on or beside the pile of larvae & 0.04540 & 0.38575 & 0.03055 \\
\hline$(14)$ & Inspecting larvae & 0.01819 & 0.00538 & 0.00194 \\
\hline$(15)$ & Carrying larvae & 0.00121 & - & - \\
\hline$(16)$ & Licking larvae & 0.03057 & 0.00134 & 0.00194 \\
\hline$(17)$ & Helping larvae to pupate & 0.00816 & - & - \\
\hline$(18)$ & Standing on or beside the pile of pupae & 0.04537 & 0.04032 & 0.08972 \\
\hline (19) & Inspecting pupa & 0.01792 & 0.00269 & 0.00970 \\
\hline$(20)$ & Carrying pupa & 0.00304 & - & - \\
\hline$(21)$ & Licking pupa & 0.00529 & - & - \\
\hline$(22)$ & Helping individual to emerge & 0.00007 & - & - \\
\hline \multicolumn{5}{|c|}{ (C) Feeding } \\
\hline$(23)$ & Feeding larvae with solid food & 0.01221 & - & 0.00048 \\
\hline$(24)$ & Worker-larva food of transfer & 0.00094 & - & 0.00048 \\
\hline$(25)$ & Feeding with solid & 0.02054 & - & 0.00533 \\
\hline$(26)$ & Cannibalism of immature & 0.00289 & 0.00134 & 0.00097 \\
\hline$(27)$ & Feeding of detritus & 0.00049 & - & - \\
\hline$(28)$ & Ovipositing trophic eggs & 0.00079 & - & 0.00048 \\
\hline \multicolumn{5}{|c|}{ (D) Nest Defense } \\
\hline (29) & Guarding the entrance to the nest & 0.03349 & - & - \\
\hline \multicolumn{5}{|c|}{ (E) Colony Maintenance } \\
\hline$(30)$ & Carrying material in the nest & 0.00175 & - & - \\
\hline$(31)$ & Carrying detritus & 0.00796 & - & - \\
\hline$(32)$ & Licking walls of the chambers & 0.00042 & - & 0.00048 \\
\hline$(33)$ & Inspecting the nest & 0.02568 & 0.00134 & 0.00630 \\
\hline \multicolumn{5}{|c|}{ (F) Foraging } \\
\hline$(34)$ & Foraging & 0.11702 & - & 0.00533 \\
\hline \multicolumn{5}{|c|}{ (G) Reproduction } \\
\hline$(35)$ & Ovipositing reproductive eggs & - & 0.00672 & - \\
\hline \multicolumn{5}{|c|}{ (H) Antennation } \\
\hline$(36)$ & Touch workers with antennas & 0.00786 & 0.00941 & 0.02861 \\
\hline$(37)$ & Touch queen with antennas & 0.00079 & 一 & 0.00048 \\
\hline
\end{tabular}


TABle 2: Continued.

\begin{tabular}{lccc}
\hline Categories and behavioral acts & Workers & Queens & Unmated gynes \\
\hline (I) Immobility & & & \\
(38) Immobility & 0.39858 & 0.18817 & 0.70514 \\
(J) Other Behaviors & & & \\
(39) Moving inside the nest & 0.00472 & 0.00806 & -02328 \\
(40) Carrying workers & 0.00133 & - & - \\
(41) Carrying males & 0.00010 & - & - \\
(42) Carrying queens & 0.00002 & - & - \\
\hline
\end{tabular}

TABle 3: Number of acts from behavioral repertoires in different species of poneromorph ants ( $W=$ worker; $Q=q u e e n ; G=g y n e)$.

\begin{tabular}{llcc}
\hline Species & Subfamily & Number of behavioral acts & References \\
\hline Ectatomma brunneum & Ectatomminae & $?$ & Overal [19] \\
Ectatomma tuberculatum & Ectatomminae & $?$ & Lachaud and Fresneau [18] \\
Ectatomma permagnun & Ectatomminae & $40 ?$ & Paiva and Brandão [12] \\
Ectatomma ruidum & Ectatomminae & $?$ & Corbara et al. [20] \\
Ectatomma opaciventre & Ectatomminae & $27 \mathrm{~W} ; 7 \mathrm{Q}$ & Pie [22] \\
Ectatomma planidens & Ectatomminae & $42 \mathrm{~W} ; 28 \mathrm{Q}$ & Antonialli-Junior et al. [13] \\
Ectatomma opaciventre & Ectatomminae & $47 \mathrm{~W} ; 12 \mathrm{Q}$ & Miguel and Del-Claro [23] \\
Ectatomma vizottoi & Ectatomminae & $42 \mathrm{~W} ; 19 \mathrm{Q} ; 24 \mathrm{G}$ & This work \\
Gnamptogenys horni & Ectatomminae & $31 ?$ & Pratt [25] \\
\hline
\end{tabular}

ovarian development were found (Figure 3, IA-C): 67\% of the analyzed workers had two filamentous ovarioles, without oocytes (Figure 3, IA); 25\% had more defined ovaries, with oocytes in the initial stage (Figure 3, IB); $8 \%$ had two ovarioles, with more developed oocytes in comparison to the previous case (Figure 3, IC).

The results showed that only one queen of each colony was inseminated (Figure 3, IIA), and therefore the other queens were confirmed as unmated gynes. All queens and unmated gynes possess 7 and 5 ovarioles in the left and right ovaries, respectively, totaling 12 ovarioles (Figure 3, IIA-D). The queens of all colonies had developed ovaries, with mature oocytes, a corpus luteum and spermatheca filled with sperm (Figure 3, IIA).

For unmated gynes, three different degrees of ovarian development were found. In the first type, most of the ovarioles were little developed, each with one large and several smaller oocytes, with the presence of a corpus luteum and empty spermatheca (not sperm) (Figure 3, IIB). In the second type, there are two developed ovarioles, each with one large and another smaller oocyte, with a corpus luteum and empty spermatheca (Figure 3, IIC). In the third type, all 12 ovarioles were filamentous, with a few small oocytes and empty spermatheca (Figure 3, IID).

\section{Discussion}

The sample coverage value shows that the behavioral repertoire can be considered complete, according to Fagen and Goldman [32]. The number of behavioral tasks was very close to those described for other species of Ectatomminae ants (Table 3).
The tasks related to "grooming/interaction" (Table 2) were also described for E. planidens [13], E. permagnum [12], and E. opaciventre [22, 23]. Allogrooming is defined by Hölldobler and Wilson [6] as the act of grooming the body of another individual. One of the functions of grooming the body is to impregnate the cuticle of the nestmate with the odor of the colony, which is related to the content of cuticular hydrocarbons or surface pheromones present in the exoskeleton [6]. Studies performed in E. vizottoi have shown that the cuticular hydrocarbons can be involved in the process of recognizing nestmates and distinguishing the castes within the colony [34]. Also, the grooming of the body is a way to inhibit the proliferation of microorganisms; studies such as that by Vieira et al. [35] have revealed that derived ants (Atta laevigata) produce antibiotic secretion by metapleural glands.

Queens of E. vizottoi remain most of the time standing near the pile of immatures, while unmated gynes and workers spend most of the time performing other tasks. In fact, activities involving "brood care" were significant in the repertoire of the queens (Table 2) as previously described for E. planidens [13] and E. opaciventre [23]. Still, unmated gynes in E. vizottoi performed this activity least often.

According to Hora et al. [36] queens of E. tuberculatum spend more time protecting the eggs, because they invest a large amount of energy in their production. However, in other members of Ectatomminae, such as E. permagnum [12], only workers were seen protecting the eggs. In colonies of E. permagnum [12] and Gnamptogenys horni Santschi [25] workers were never seen protecting pupae. In addition, in E. planidens [13] and E. opaciventre [23] workers were seen cannibalizing immatures. 


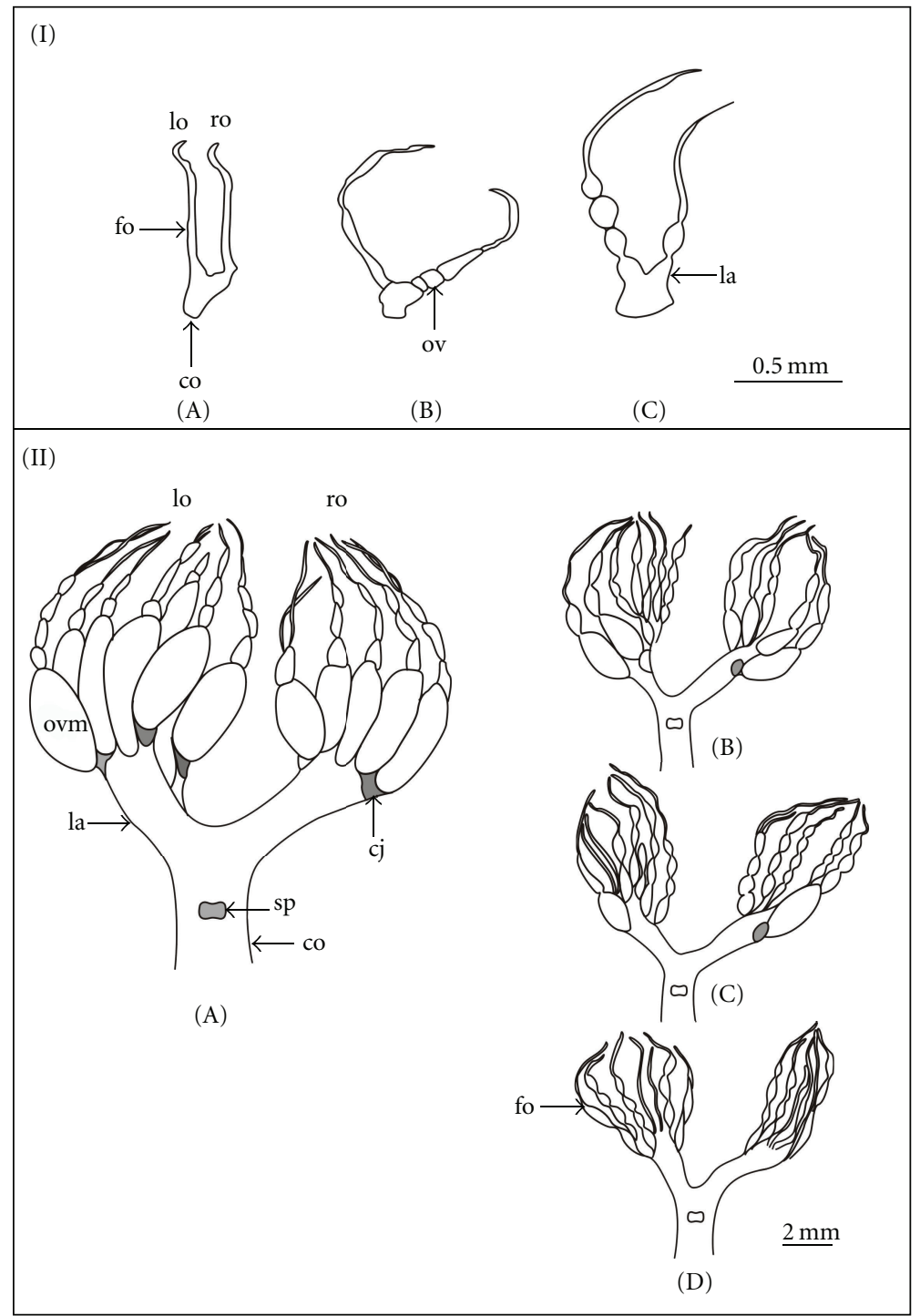

FIGURE 3: Morphological condition of the different degrees of ovarian development in workers, queens, and unmated gynes of Ectatomma vizottoi. (I) three types of ovarian development in workers (A-C), lo: left ovariole, la: lateral ovariole, co: common oviduct, ro: right ovariole, fo: filamentous ovariole, ov: oocyte. (II) A: ovaries of queens. (B-D): three degrees of ovarian development of unmated gynes. Ovm: mature oocyte, cj: corpus luteum, sp: spermatheca.

The task "worker-larva food transfer" was performed by both unmated gynes and workers (Table 2). However, in colonies of E. opaciventre [22, 23], E. tuberculatum [36] only workers fed the larvae. According to Wilson [1], ants from the subfamilies Myrmicinae, Aneuretinae, Dolichoderinae, and Formicinae exchange regurgitated food, and their intestine is modified to store and distribute food for nestmates, a process called trophallaxis. In poneromorph ants such as E. tuberculatum [37] this behavior is defined as pseudo-regurgitation, in which an individual transfers previously collected liquid food to the open jaw of a nestmate. Feeding larvae with solid items without trophallaxis is a "primitive" characteristic $[38,39]$, as is pseudotrophallaxis, which is present in the poneromorph group [36].
Both workers and unmated gynes were involved in the activity "foraging", differently from E. planidens [13] and E. opaciventre [22, 23], in which only the workers performed this task. However, Hora et al. [17] also observed unmated gynes of E. tuberculatum foraging.

During the foraging activity by the workers of this species, no recruitment of nestmates was observed, in contrast to E. brunneum [19] and G. horni [25]. The peak of foraging occurred during the morning. However, in $E$. planidens [13] and E. tuberculatum [40] this activity is more intense during the night.

Workers, unmated gynes, and queens of E. vizottoi performed the activity "inspecting the nest" (Table 2). In the colonies of E. planidens [13] and E. opaciventre [22, 23], this activity is performed only by workers. 
Although there was more than one individual with reproductive potential present, "ovipositing reproductive eggs" was performed by only one inseminated queen. The appearance of these eggs was similar to those described by Hora et al. [36] for E. tuberculatum, in which they change color from white to dark some hours after oviposition. Eggs of E. planidens [13] and E. opaciventre [22, 23] show a yellowish color. On the other hand, the trophic eggs, such as those of E. planidens [13], E. opaciventre [22, 23], and E. tuberculatum [36] are whitish. In ants, there is an inverse relationship between the existence of either trophallaxis or trophic eggs as a means of food exchange within the society [1]. Trophic eggs are efficient to furnish proteins that are necessary for vitellogenesis for reproductive eggs, and they also enable colony members to store and distribute nutrients and to survive seasonal food shortages [41, 42]. Trophic eggs produced by workers are common in many ants [6]. Although trophallaxis is absent in the poneromorphs, trophic eggs are known in five queens of the poneromorph group $[8,43]$.

The most frequent activity among the workers, queens, and unmated gynes (Table 2) was "immobility" as described for E. planidens [13]. According to Hölldobler and Wilson [6], all poecilotherms spend most of the time doing nothing in particular, except for carrying out physiological functions.

The same number of ovarioles (1-2) in the workers of E. vizottoi also occurs in the ovaries of workers of $E$. brunneum [44] and E. planidens [13]. The three degrees of ovarian development and the presence of developed oocytes (Figure 3, IA, B, and C) in E. vizottoi also occur in workers of E. brunneum [44]. However, in workers of E. planidens [13] only filamentous ovarioles were found, with no trace of developed oocytes. Probably the workers with a greater degree of ovarian development are those that show trophic oviposition, as observed in workers of E. brunneum [44]. The presence of oocytes in the reabsorption stage may indicate previous production of reproductive or trophic eggs by workers [45]. However, workers of E. vizottoi possess atrophied spermatheca (Figure 3), similarly to E. brunneum [44] and E. planidens [13]. Therefore, in Gnamptogenys menadensis Mayr [46] virgin workers may lay trophic eggs, and only mated workers produce reproductive eggs.

Queens and unmated gynes of E. vizottoi contained 12 ovarioles (Figure 3 IIA, B, C, and D), while queens of $E$. planidens [13] contained 4 and queens of E. brunneum [44] 7 to 8 ovarioles. The ovaries of the queens contain mature oocytes and sperm-filled spermatheca, in contrast to unmated gynes which do not contain sperm and also have little-developed ovarioles. This corroborates the behavioral observations, in which it was possible to identify only one queen laying reproductive eggs. Unmated gynes have never been observed laying fertilized eggs and performing activities related to "colony maintenance", and therefore show a repertoire which is more similar to the workers' than to the queen's. However, even if there are several reproductive castes in a colony, a functional monogyny occurs, in which only one queen lays fertilized eggs [17].

The presence of several queens may be the result of adoption, as described for E. permagnum [12], E. ruidum
[15], and E. tuberculatum, which, in this case, show facultative polygyny [17]. However, queens and unmated gynes showed a clear behavioral differentiation, in which queens played the role of reproducers and unmated gynes performed activities belonging to the worker repertoire. Analysis of ovarian development showed that unmated gynes had littledeveloped ovarioles, in contrast to queens. Despite the presence of several breeding queens in the colony, functional monogyny was the rule.

\section{Acknowledgments}

The authors thank Dr. Jacques Hubert Charles Delabie from the Myrmecology Laboratory of the Cocoa Research Center (Ceplac-Ilhéus, BA) for the identification of the specimens, and voucher specimens were deposited under no. 2196; Dr. Riviane R. Hora for her help in the ovarian development study; Thiago dos Santos Montagna (PPGECB) for help in the maintenance of the colonies; Janet W. Reid for the linguistic revision. They are grateful to Capes for a grant awarded to the first author, Fundect (Fundação de Apoio à Pesquisa de Mato Grosso do Sul) for financial support (Grant no. 23/200.085/2007) and CNPQ for a productivity grant to W. F. Antonialli-Junior.

\section{References}

[1] E. O. Wilson, The Insect Societies, Harvard University Press, Cambridge, Mass, USA, 1971.

[2] W. Gronenberg, "Neuroethology of ants," Naturwissenschaften, vol. 83, no. 1, pp. 15-27, 1996.

[3] G. Oster and E. O. Wilson, Caste and Ecology in the Social Insects, vol. 12, Princeton University Press, Princeton, NJ, USA, 1978.

[4] A. F. G. Bourke and N. R. Franks, Social Evolution in Ants, Princeton University Press, Princeton, NJ, USA, 1995.

[5] B. Bolton, Synopsis and Classification of Formicidae, Memoirs of the American Entomological Institute, Gainesville, Fla, USA, 2003.

[6] B. Hölldobler and E. O. Wilson, The Ants, Spring, Berlin, Germany, 1990.

[7] C. P. Peeters, "Monogyny and polygyny in ponerine ants with and without queens," in Queen Number and Sociality in Insects, L. Keller, Ed., pp. 234-261, Oxford University Press, New York, NY, USA, 1993.

[8] C. P. Peeters, "Morphologically "primitive" ants: comparative review of social characters, and the importance of queenworker dimorphism," in The Evolution of Social Behavior in Insects and Arachnids, J. C. Choe and B. J. Crespi, Eds., pp. 372-391, Cambridge University Press, 1997.

[9] K. C. Jaffé, El Mundo de las Hormigas, Equinoccio, Baruta, Venezuela, 1993.

[10] F. H. Caetano, K. Jaffé, and F. J. Zara, Formigas: Biologia e Anatomia, F. H. C., 2002.

[11] C. R. F. Brandão, "Sequential ethograms along colony development of Odontomachus affinis Guérin (Hymenoptera, Formicidae, Ponerinae)," Insectes Sociaux, vol. 30, no. 2, pp. 193-203, 1983. 
[12] R. V. S. Paiva and C. R. F. Brandão, "Estudos sobre a organização social de Ectatomma permagnum Forel, 1908 (Hymenoptera: Formicidae)," Revista Brasileira de Biologia, vol. 49, no. 3, pp. 783-792, 1989.

[13] W. F. Antonialli-Junior, V. C. Tofolo, and E. Giannotti, "Population dynamics of Ectatomma planidens (Hymenoptera: Formicidae) under laboratory conditions," Sociobiology, vol. 50, no. 3, pp. 1005-1013, 2007.

[14] W. F. Antonialli-Junior and E. Giannotti, "Division of labor in Ectatomma edentatum," Sociobiology, vol. 39, no. 1, pp. 37-63, 2002.

[15] J. P. Lachaud, A. Cadena, B. Schatz, G. Pérez-Lachaud, and G. Ibarra-Núñez, "Queen dimorphism and reproductive capacity in the ponerine ant, Ectatomma ruidum Roger," Oecologia, vol. 120, no. 4, pp. 515-523, 1999.

[16] R. Blatrix and P. Jaisson, "Reproductive strategy of the ponerinae ant Gnamptogenys striatula Mayer (Hymenoptera: Formicidae)," Sociobiology, vol. 37, pp. 147-161, 2001.

[17] R. R. Hora, E. Vilela, R. Fénéron, A. Pezon, D. Fresneau, and J. Delabie, "Facultative polygyny in ,Ectatomma tuberculatum (Formicidae, Ectatomminae)," Insectes Sociaux, vol. 52, no. 2, pp. 194-200, 2005.

[18] J.-P. Lachaud and D. Fresneau, "Social regulation in ponerine ants," in From Individual to Collective Behavior in Social Insects, J. M. Pasteels and J.-P. Deneubourg, Eds., vol. 54 of Basel Experientia Supplementum, pp. 197-217, Birkähuser, 1987.

[19] W. L. Overal, "Recrutamento e divisão de trabalho em colônias naturais da formiga Ectatomma quadridens (Fabr.) (Hymenoptera: Formicidae: Ponerinae)," Boletim do Museu do Para. Emilio Goeldi, Zoologia, vol. 2, no. 2, pp. 113-135, 1986.

[20] B. Corbara, J. P. Lachaud, and D. Fresneau, "Individual variability, social structure and division of labour in the ponerine and Ectatomma ruidum Roger (Hymenoptera: Formicidae), Ethology, vol. 82, pp. 89-100, 1989.

[21] S. C. Pratt, "Recruitment and other communication behavior in the ponerine ant Ectatomma ruidum," Ethology, vol. 81, pp. 313-331, 1989.

[22] M. R. Pie, "Behavioral repertoire, age polyethism and adult transport in Ectatomma opaciventre (Formicidae: Ponerinae)," Journal of Insect Behavior, vol. 15, no. 1, pp. 25-35, 2002.

[23] T. B. Miguel and K. Del-Claro, "Polietismo etário e repertório comportamental de Ectatomma opaciventre Roger, 1861 (Formicidae, Ponerinae)," Revista Brasileira de Zoociencias, vol. 7, no. 2, pp. 297-310, 2005.

[24] A. S. Vieira, W. F. Antonialli, and W. D. Fernandes, "Modelo arquitetônico de ninhos da formiga Ectatomma vizottoi Almeida (Hymenoptera, Formicidae)," Revista Brasileira de Entomologia, vol. 51, no. 4, pp. 313-317, 2007.

[25] S. C. Pratt, "Ecology and behavior of Gnamptogenys horni (Formicidae: Ponerinae)," Insectes Sociaux, vol. 41, no. 3, pp. 255-262, 1994.

[26] W. F. Antonialli and E. Giannotti, "Nest architecture and population dynamics of the ponerine ant Ectatomma edentatum (Hymenoptera, Formicidae)," Sociobiology, vol. 38, no. 3, pp. 475-486, 2001.

[27] E. O. Wilson, "Leptothorax duloticus and the beginnings of slavery in ants," Evolution, vol. 29, pp. 108-119, 1975.

[28] C. R. F. Brandão, "Division for labor within the worker caste of Formica perpilosa Wheeler (Hymenoptera: Formicidae)," Psyche, vol. 85, no. 2-3, pp. 229-237, 1978.

[29] A. Drogoul, B. Corbara, and D. Fresneau, "Applying ethomodelling to social organization in ants," in Biology and Evolution of Social Insects, pp. 375-383, Leuven University Press, Leuven, Belgium, 1992.
[30] K. Nakata, "The difference in behavioral flexibility among task behaviors in a ponerine ant, Diacamma sp," Sociobiology, vol. 27, no. 2, pp. 119-128, 1996.

[31] J. Altmann, "Observational study of behavior: sampling methods," Behaviour, vol. 49, no. 3-4, pp. 227-267, 1974.

[32] R. M. Fagen and R. N. Goldman, "Behavioural catalogue analysis methods," Animal Behaviour, vol. 25, no. 2, pp. 261$274,1977$.

[33] H. Wolda, "Similarity indices, sample size and diversity," Oecologia, vol. 50, no. 3, pp. 296-302, 1981.

[34] W. F. Antonialli, S. M. Lima, L. H. C. Andrade, and Y. R. Súarez, "Comparative study of the cuticular hydrocarbon in queens, workers and males of Ectatomma vizottoi (Hymenoptera, Formicidae) by Fourier transform-infrared photoacoustic spectroscopy," Genetics and Molecular Research, vol. 6, no. 3, pp. 492-499, 2007.

[35] A. S. Vieira, O. C. Bueno, and M. I. Camargo-Mathias, "The functional morphology of the metapleural gland of the leafcutting ant Atta laevigata (Formicidae: Attini)," Micron, vol. 41, no. 2, pp. 149-157, 2010.

[36] R. R. Hora, C. Poteaux, C. Doums, D. Fresneau, and R. Fénéron, "Egg cannibalism in a facultative polygynous ant: conflict for reproduction or strategy to survive?" Ethology, vol. 113, no. 9, pp. 909-916, 2007.

[37] F. J. Richard, A. Dejean, and J. P. Lachaud, "Sugary food robbing in ants: a case of temporal cleptobiosis," Comptes Rendus-Biologies, vol. 327, no. 5, pp. 509-517, 2004.

[38] B. Hölldobler and E. O. Wilson, "Ecology and Behavior of the primitive cryptobiotic ant Prionopelta amabilis (Hymenoptera: Formicidae)," Insectes Sociaux, vol. 33, no. 1, pp. 45-58, 1986.

[39] J. F. A. Traniello and A. K. Jayasuriya, "The biology of the primitive ant Aneuretus simoni (Emery) (Formicidae: Aneuretinae) II. The social ethogram and division of labor," Insectes Sociaux, vol. 32, no. 4, pp. 375-388, 1985.

[40] N. A. Weber, "Two commom ponerine ants of possible economic significance, Ectatomma tuberculatum (Oliver) and E. ruidum Roger," Proceedings of the Entomological Society of Washington, vol. 48, no. 1, pp. 1-16, 1946.

[41] S. H. Voss, J. F. Mcdonald, and C. H. Keith, "Production and abortive development of fire ant trophic eggs," in Advances in Myrmecology, J. C. Trager, Ed., pp. 517-534, 1998.

[42] B. J. Crespi, "Cannibalism and trophic eggs in subsocial and eusocial insects," in Cannibalism: Ecology and Evolution among Diverse Taxa, M. A. Elgar and B. J. Crespi, Eds., pp. 176-213, Oxford University Press, Oxfordm, UK, 1992.

[43] B. Gobin, C. Peeters, and J. Billen, "Production of trophic eggs by virgin workers in the ponerine ant Gnamptogenys menadensis," Physiological Entomology, vol. 23, no. 4, pp. 329336, 1998.

[44] L. V. Toledo-Mello and F. H. Caetano, "Padrões morfológicos do ovário de formigas Ectatomma quadridens (Hymenoptera: Ponerinae) e suas implicações funcionais," Rio Claro, 16p, (Trabalho de formatura-UNESP, Rio Claro, SP), 1980.

[45] M. W. J. Crossland, R. H. Crozier, and E. Jefferson, "Aspects of the biology of the primitive ant genus Myrmecia F. (Hymenoptera: Formicidae)," Journal of the Australian Entomological Society, vol. 27, no. 4, pp. 305-309, 1988.

[46] B. Gobin, C. Peeters, and J. Billen, "Colony reproduction and arboreal life in the ponerine ant Gnamptogenys menadensis (Hymenoptera: Formicidae)," Netherlands Journal of Zoology, vol. 48, no. 1, pp. 53-63, 1998. 

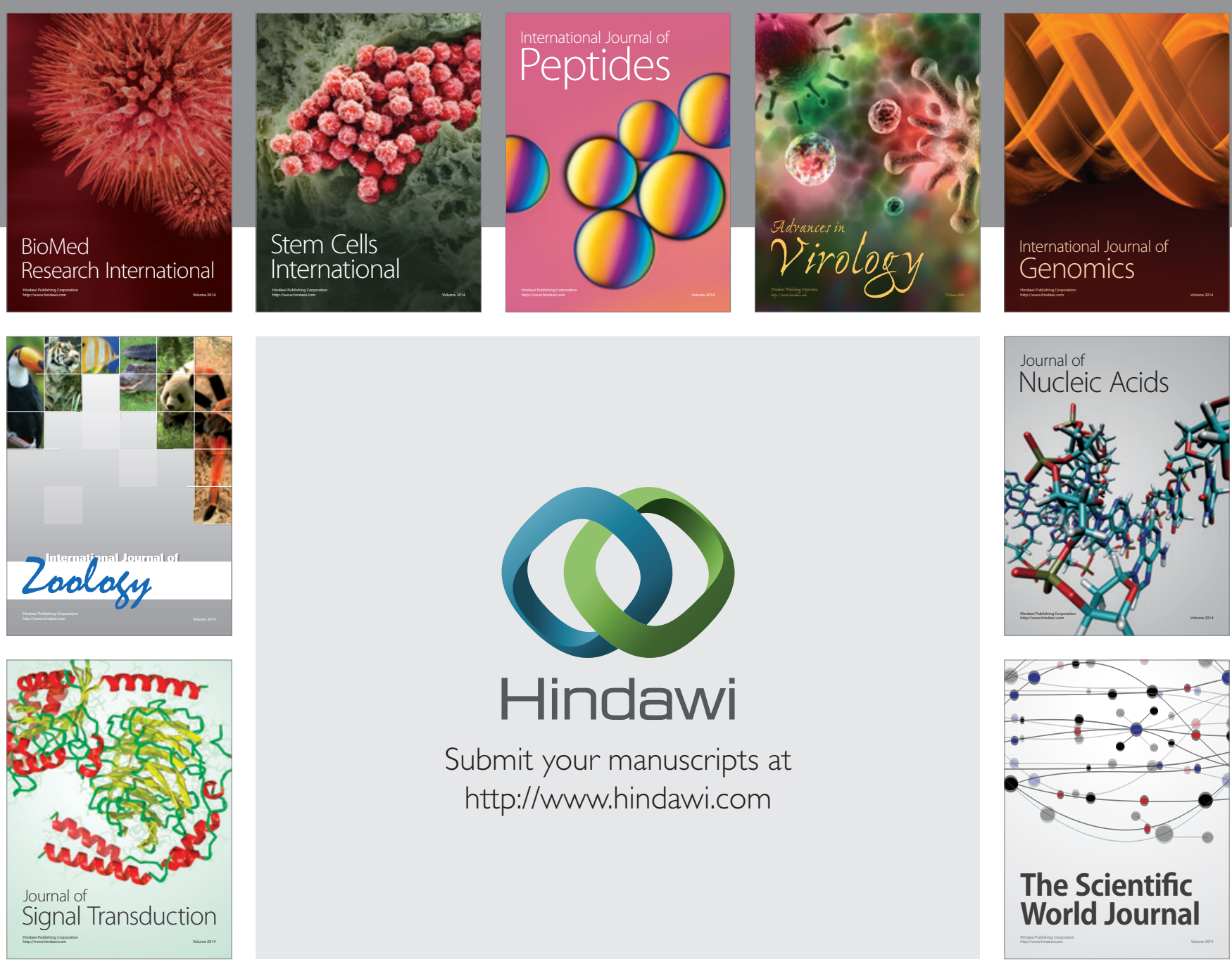

Submit your manuscripts at

http://www.hindawi.com
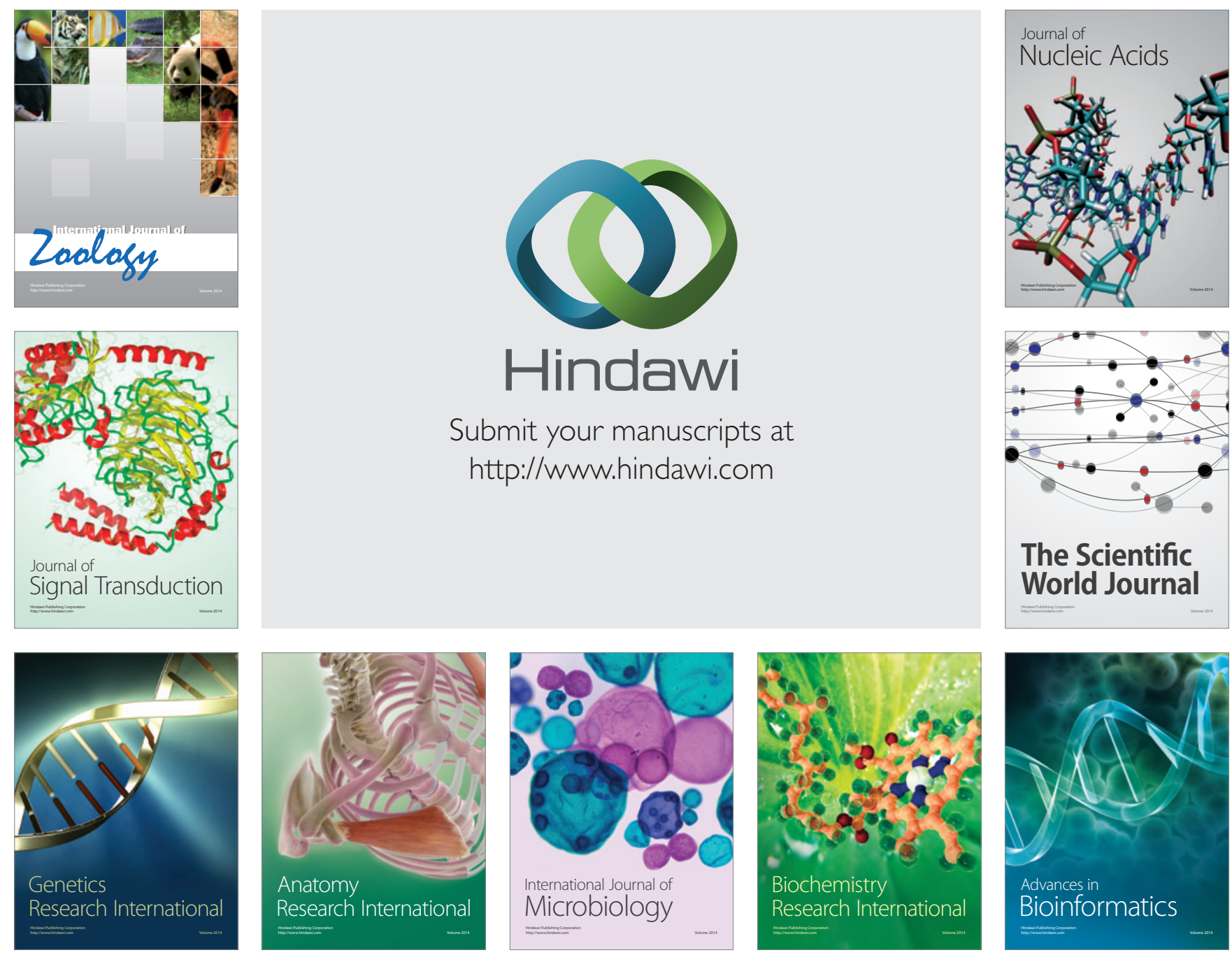

The Scientific World Journal
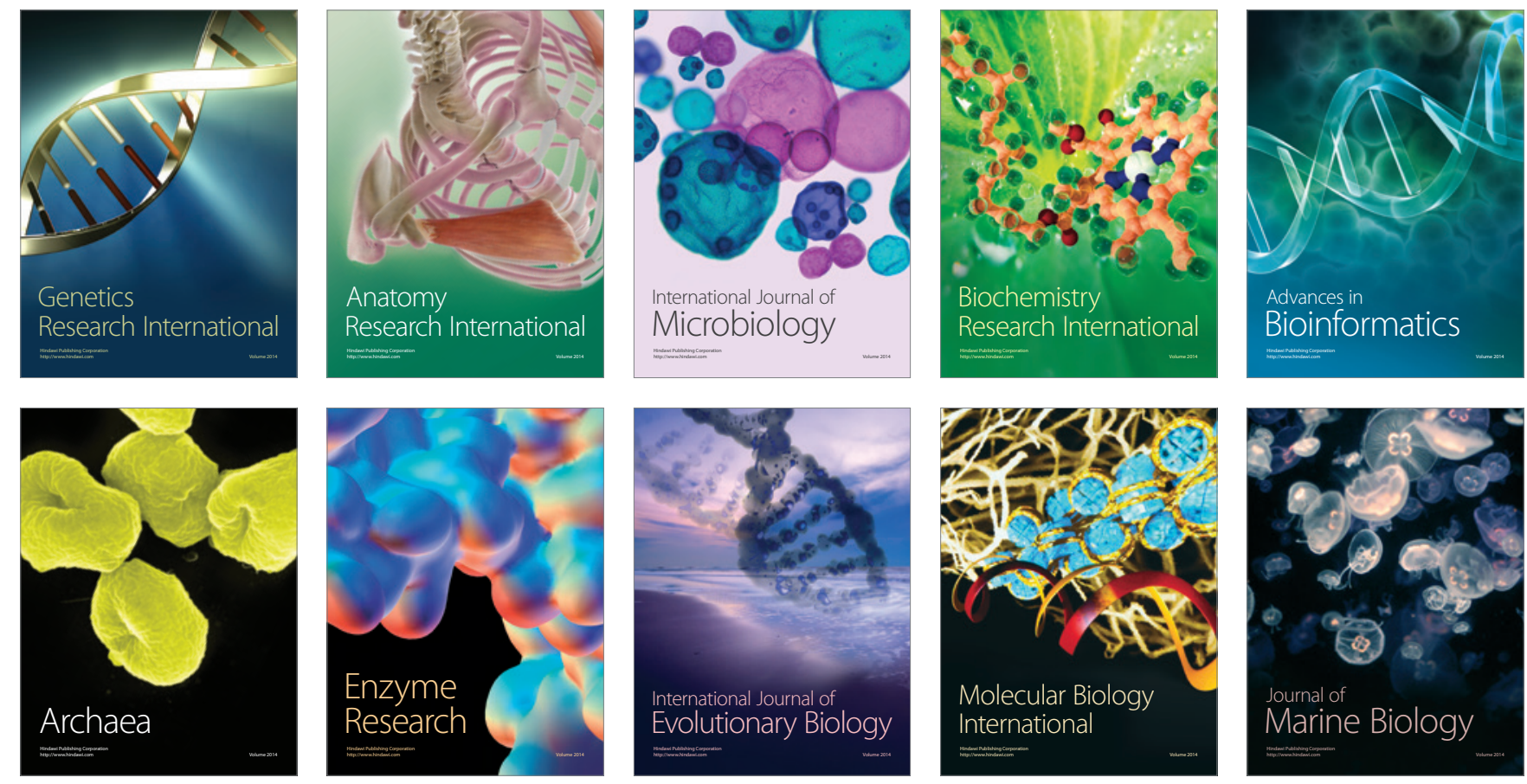